\title{
Paulo e o Ecumenismo
}

\author{
Maria Teresa de Freitas Cardoso
}

\section{Introdução}

Sabemos que a teologia paulina é um mundo vastíssimo. Nela encontramos diversos princípios doutrinais da fé cristã, diretrizes espirituais e toda sorte de aconselhamento prático. Boa parte do Novo Testamento é considerada paulina. Neste trabalho indicamos alguns aspectos dessa riqueza, que se faz sempre objeto de renovado interesse. Nosso propósito aqui é acentuar como tem sido importante a contribuição paulina no campo do ecumenismo

A teologia paulina é rica em propostas para o ecumenismo. Impressiona a clareza de princípios teológicos que fundamentam e favorecem a tarefa ecumênica. Ali se encontram exortações e reprimendas, conselhos e sugestões que ajudam a balizar e a desenvolver também o ecumenismo.

Isso não podia deixar de se refletir nos empreendimentos do movimento ecumênico. Os documentos ecumênicos já utilizam o apóstolo Paulo. Muitos livros que se interessam pelo ecumenismo consideram a sua teologia. As atividades ecumênicas, mundo afora, muitas vezes têm pretendido aplicar de algum modo várias de suas idéias e a própria Semana de Oração pela Unidade dos Cristãos bebeu inúmeras vezes dos textos sagrados paulinos. Cabe pensar, entretanto, que a contribuição do Apóstolo Paulo para o ecumenismo poderia ainda mais ser colocada em evidência e tornar-se pauta de discussão e prática do ecumenismo, visto que o ecumenismo se faz uma tarefa para todos os cristãos, torna-se mesmo prioridade em nossos tempos, supõe bons critérios e, 
enfim, espera um impulso renovado. Por outro lado, o Apóstolo Paulo tem significativa potencialidade para iluminar o ecumenismo.

Esse é um dado a ser observado quando se tem falado do Apóstolo Paulo, de sua pujante teologia, de sua relação com helenismo e judaísmo, e quando se procura fazer valer aporte de um Ano Paulino. Falaremos aqui da contribuição paulina sem distinguir a discussão das cartas proto ou deuteropaulinas.

\section{Na perspectiva do ecumenismo}

Muito se fala sobre o ecumenismo. As idéias se entrecruzam e variam entre si. Variam em função do que se compreende por ecumenismo e em função de como se aprecia o ecumenismo ou se medem ou se abrem as suas possibilidades de realização.

Qual o conceito de ecumenismo? O modo de usar o termo pode variar desde a referência a um círculo mais estrito ou mais amplo. No sentido mais estrito, estaria se referindo aos cristãos que empreendem um movimento de aproximação ou maior unidade com outros cristãos de diferentes confissões ou denominações. Num sentido mais amplo, envolveria a aproximação e o diálogo entre pessoas de diferentes credos ou religiões.

A nosso entender, ambos os círculos são importantes de se considerar. Nem se deve restringir a abertura do coração apenas aos demais cristãos, como se fosse impossível um interesse e uma aproximação ou colaboração com pessoas que têm outras concepções religiosas, nem se deve, em nome de uma abertura a todos, deixar de cultivar os laços que já nos reúnem aos cristãos àqueles que também confessam o Cristo Salvador, a Trindade, a Bíblia como Palavra de Deus... como se unidade entre nós não precisasse ainda de cuidados. Na verdade, julgamos que as duas solicitudes têm, cada uma, a sua especificidade, mas sem deixarem de estar aparentadas e de se iluminarem mutuamente. $\mathrm{O}$ que se promove em um campo, de certo modo pode ser continuado no outro campo, e um cuidado favorece o outro. Assim, cristãos que dialogam, são exercitados numa arte de diálogo que os prepara para um diálogo mais amplo, são mesmo impelidos para fazerem crescer seu círculo de relação fraterna. Quem coopera para a paz, ou procura semeá-la, no âmbito mais universal, é chamado a vivê-la também "dentro de casa".

Com isso pretendemos mostrar alguns aspectos da teologia paulina para o ecumenismo, considerado de modo geral, tanto estritamente como amplamente. Distinguiremos alguns aspectos dos laços que nos envolvem ou da aproximação que nos haveria de envolver a todos, mesmo universalmente. Mas essa distinção metódica não pretende senão fazer aproveitar elementos comuns dos cristãos, ou contribuições paulinas para o diálogo mais universal. 
De modo algum se pretende criar novos muros. Ao contrário, como se poderá notar, de um campo somos convidados a alargar o desejo e a tarefa de ecumenismo. Hoje, quando se fala de ecumenismo se deseja e se pretende um envolvimento que leve à paz e à cooperação entre todos nós. O termo "ecumênico" tem sua origem em sentido universalista. "Oikoumene" era toda a terra habitada, era o universo das pessoas.

Entretanto, cabe salientar como se consolida o ecumenismo também concretamente entre cristãos, para que, na troca e no apoio, melhor aproveitem de seu patrimônio comum. O diálogo inter-religioso não precisa esperar que a unidade dos cristãos seja perfeita, mas também pode se beneficiar de que os cristãos se apóiem mutuamente também na atitude de diálogo e melhor se sintam estimulados para a fraternidade que, segundo a fé cristã, não deve encontrar fronteiras. Paulo ilumina o ecumenismo interno dos cristãos e Paulo deixa princípios para a superação de preconceitos e para se buscar uma situação de amor e de reconciliação universal.

Como se faz o ecumenismo concretamente? O Concílio Vaticano II, no seu Decreto sobre o ecumenismo, "Unitatis Redintegratio", caracteriza o movimento ecumênico em movimento de restauração de unidade, nascido por obra do Espírito Santo. ${ }^{1} \mathrm{O}$ mesmo decreto exorta à participação do movimento ecumênico pela oração, pela palavra e pela ação. ${ }^{2}$ Podem-se ver aqui as três principais vertentes do ecumenismo: o ecumenismo espiritual, o diálogo da palavra, a colaboração ecumênica, vertentes estas que naturalmente se entrecruzam. Paulo ilumina a unidade, e a unidade será buscada em todos esses caminhos.

Como falávamos, a unidade é um desejo que se abre mais universalmente do que o campo dos cristãos. Deseja-se alcançar uma unidade que abrace todas as pessoas. O diálogo se estende a quem desejar dialogar. Respeitemse as convicções, mas haja uma atitude de boa vontade com o outro, de confiança na boa fé de cada um, de apreciação da riqueza também de cada qual. Isso para todas as pessoas, qualquer que seja a sua convicção religiosa. E descobrem-se muitos pontos comuns. Como se sabe, a relação da Igreja Católica com as demais religiões tem sido tratada pela Igreja Católica levando em conta a Declaração "Nostra Aetate". Tem recebido o nome de "diálogo interreligioso", e hoje tem sido considerado, usualmente em nossa sociedade, tam-

\footnotetext{
1 "E também, por obra do Espírito Santo, surgiu, entre nossos irmãos separados, um movimento sempre mais amplo para restaurar a unidade de todos os Cristãos, movimento de unidade que é chamado movimento ecumênico". Cf. CONCÍLIO VATICANO II, Decreto Unitatis Redintegratio (UR), n. 1, in Compêndio do Vaticano II. Constituições, Decretos, Declarações, Vozes, Petrópolis, $21^{\mathrm{a}}$, 1991.

${ }^{2} U R$, n. 4.
} 
bém como "ecumenismo". Também nesse campo, os cristãos se beneficiam de Paulo, especialmente por ele afirmar o respeito, a unidade, a reconciliação e a paz. Ou na atitude de Paulo, quando entra em diálogo com os contemporâneos.

\section{O Apóstolo Paulo fala ao ecumenismo}

Podemos dizer que falam ao ecumenismo o modo de Paulo se relacionar com judaísmo e com helenismo e também o seu modo de tratar a fé cristã e a prática cristã nas diversas comunidades.

\subsection{Nas suas relações com judaísmo e helenismo}

Paulo é judeu, com formação helenística e cidadão romano. O modo do Apóstolo Paulo se relacionar com judaísmo e com helenismo refletem tanto sua origem e sua formação, como sua identidade cristã e sua atitude ao mesmo tempo evangelizadora e dialogal. Até a missão não suprime o diálogo nem muito menos as origens.

Paulo é cristão, pois segue Cristo (afirma "para mim viver é Cristo") mas tendo sido e conservando-se significativamente um judeu, com uma cultura que tem contacto importante com o helenismo. Sua teologia cristã é rica de contribuições que provêm de todos esses contactos. Seu modo de pensar reflete essas prerrogativas e sua teologia dialoga com diferentes vertentes de convicção religiosa, cultura e experiência de vida.

Pode-se fazer todo um simpósio para se aproveitar do relacionamento de Paulo com judaísmo e helenismo, e não se esgotará o assunto. No que diz respeito ao ecumenismo, porém, não se pode deixar de observar que as origens e a atitude do Apóstolo sugerem passos importantes. Paulo tem origens judaicas e bebe do judaísmo. Mesmo como cristão, usa desse patrimônio espiritual e o propõe. Ele leva adiante a sua opção religiosa pela transformação de uma experiência com Cristo, e, abraçando o caminho cristão, perfaz a sua identidade com um novo matiz, dando também vida nova ao seu pensamento e à sua atividade. Por outro lado, ele aproveita do contacto com o helenismo e usa de seus conceitos e de suas imagens. Paulo Apóstolo representa um encontro privilegiado, uma síntese de diálogo que pode se tornar simbólica. Não estamos tratando aqui de impor um elemento mais judaico ou uma nota mais cristã, ou seguir ou não uma concepção helênica, mas estamos levando em conta que existiu em Paulo uma abertura, um respeito, um compartilhamento, um aproveitamento. Ou repetimos, uma síntese do que pode ser um diálogo. E por isso ele pode ser um símbolo do diálogo. 
Podemos dizer, por isso, que a teologia cristã paulina bebe, portanto, da origem judaica junto com o dado cristão da revelação de Cristo, e se está em contacto com helenismo. Além da própria formação cultural e religiosa, e de sua experiência de vida, cabe incluir a prática de Paulo que leva em conta língua, conceitos, perguntas e expectativas que ele percebe presente nos ouvintes e nas comunidades, e leva para a sua própria contribuição. E tudo isso se reflete ou se aproveita em perspectivas e contribuições do próprio Paulo, em seu pensamento, linguagem, espiritualidade e disposições práticas. Observemos que isso se faz também com a originalidade e a vivacidade típicas do Apóstolo. Paulo usa de métodos de argumentação que recebeu, mas os traz com seu modo próprio. Assim, o diálogo dá lugar à sua própria contribuição.

Isso é inspirador para todo diálogo, que há de aproveitar da instrução e formação que se tem, contar com a pessoa e o mundo do interlocutor, permitirse pensar e falar de modo próprio, novo e enriquecedor, se assim for oportuno e possível para quem dialoga, como recebendo a contribuição do outro.

Por tudo isso, o Apóstolo Paulo se torna símbolo de encontro e diálogo. Pode ser uma referência inspiradora para o ecumenismo. Pode ser levado para iluminar as atitudes fundamentais do ecumenismo, que guarda o respeito ao outro bem como à própria identidade, assim como da própria experiência religiosa, bem como a abertura para o acolhimento do outro e possíveis contribuições do encontro, do pensamento, da vida. Para tratar perguntas que são lançadas ao diálogo e até lançar-se a novos aprofundamentos da fé.

Desse modo, entre os primeiros passos do ecumenismo estão a aproximação, o encontro e o acolhimento. Está uma atitude de abertura, respeitosa e acolhedora do outro, que acolhe desde suas perguntas e expectativas, até suas contribuições para a discussão, com conceitos, imagens ou o aproveitamento de um tema ou pensamento. Pode haver um discernimento, pode acontecer uma diferença de pensamento, em que cada um pode ter a sua convicção, sem que isso diminua a estima mútua e o empenho de colaborar. Por isso, pode-se e deve-se colher a contribuição do outro como um dom. O diálogo pode trazer, de um interlocutar ou de outro, ou do encontro de ambos, um dado novo, esclarecedor, oportuno, enriquecedor.

\subsection{Fé e vida, na perspectiva cristã}

Fala também ao ecumenismo o modo de Paulo tratar a fé cristã e o modo de Paulo conduzir a prática cristã nas diversas comunidades que evangeli$\mathrm{za}$, ou às quais escreve.

Referimo-nos à identidade cristã, como dado ou convicção que nasce em meio à tradição judaica mas iluminado pelo encontro com Cristo e o evan- 
gelho de Cristo. De certo modo, também podemos nos referir à solicitude que Paulo tem para com os cristãos a propósito das perguntas que lhe trazem, ou fazem, que ele procura discutir em luz cristã. E, sobretudo, às exortações para uma prática que seja coerente com o que se anuncia e se professa.

Falando de modo tão simplificado, diríamos que Paulo se dedica à consideração da fé abraçada, com a entrega da vida pessoal a Cristo, e se preocupa largamente também com a vida comunitária, que deve expressar a unidade do corpo de Cristo. Se palmilhássemos as cartas, haveria ainda uma quantidade de aspectos a caracterizar o cristão e a Igreja. Paulo ilumina as questões das comunidades e exorta à prática cristã. Fé e vida se implicam mutuamente. A identidade cristã que se revela na teologia paulina envolve tanto a vida pessoal de fé como a comunidade eclesial.

Para o ecumenismo tudo isso é importante. Em primeiro lugar pela atenção com a conviç̧ão cristã. Aqui pensamos também na identidade confessional dos interlocutores do diálogo ecumênico. O ecumenismo é uma atitude que vai ao encontro e dialoga, mas não anula o que acredita, não anula a própria identidade confessional. Mais ainda, o ecumenismo será mais vivo e eficaz se também a prática da fé corresponde melhor ao que se crê e anuncia, oferecendo ao diálogo e ao convívio o testemunho e as contribuições do caminho de vida sinceramente abraçado.

Com isso tudo, o ecumenismo guarda o respeito da identidade, e, destarte, aquele que participa do ecumenismo pode guardar a própria confissão de fé bem como ter sua prática de vida coerente com as opções fundamentais. É assim que cada um entrará em diálogo. Não para impor sua convicção, mas com o direito de guardá-la, professá-la e até apresentá-la para explicar o seu pensamento e a sua prática. É interessante também a crescente iluminação dessa identidade: ver que a fé cristã se pode tratar, e conhecer mais profunda e vivamente, e que no diálogo as convicções se revelam e, umas com as outras, muitas vezes se enriquecem.

Quanto ao ecumenismo considerado no sentido mais amplo, lá também se desejará ver e favorecer que os valores religiosos e humanos sejam respeitados na fé e na vida, e os cristãos deveriam chegar com seu testemunho coerente, bem como respeitar e apreciar a implicação entre convicção e vida do seu interlocutor.

\section{Alguns tópicos paulinos de unidade}

Existem vários tópicos da teologia paulina que implicam em unidade. Aparecem com diferentes propósitos e matizes em lugares diferentes, seja das grandes cartas, seja do cativeiro ou das pastorais. Assim temos várias referên- 
cias ao batismo, ou à Ceia eucarística, temos a teologia do Corpo de Cristo, referida ao Corpo individual, seja ao Corpo eclesial. Temos o tema da reconciliação. Temos a exigência da caridade. Em um artigo de abordagem ampla, mal podemos nos deter ou mesmo tocar um ou outro aspecto, de modo que faremos uma seleção de alguns textos para inspirar a busca ou a vida de unidade. São, de fato, tópicos muito interessantes para o ecumenismo. Não os trataremos aqui segundo o progresso da teologia paulina tomada nas grandes cartas, cativeiro e pastorais. Apenas os mencionamos, em outra ordem, como pontos destacados ilustrativos, em ordem que favorece melhor os tópicos de nossas observações.

\subsection{Sois um só em Cristo Jesus}

É importante a teologia do batismo no Apóstolo Paulo. Inúmeros textos fazem ressoar o tema do batismo. Interessa-nos acentuar que o batismo se liga ao tema da unidade em Cristo. Um texto fundamental aponta para essa unidade e, a partir de Cristo, de quem o cristão se reveste, faz superar toda sorte de discriminação. As contraposições mais presentes no pensamento dos ouvintes são reconduzidas à unidade: "Todos vós, que fostes batizados em Cristo, vos vestistes de Cristo. Não há judeu nem grego, não há escravo nem livre, não há homem nem mulher, pois todos vós sois um só em Cristo Jesus" (Gl 3,28).

$\mathrm{O}$ ecumenismo que se ilumina com Paulo e aceita esse dado neotestamentário, também não dará lugar a discriminações e preconceitos, mas salvaguardará o respeito e a dignidade de todos, na unidade de Cristo, unificados em Cristo, todos revestidos do mesmo Cristo e no Espírito de Cristo. Cristo unifica. Quando as pessoas ecumenicamente se olharem na unidade do Cristo, que anula os antagonismos, então se cumprirá uma meta do ecumenismo à luz de Paulo.

Essa atitude cristã de superar antagonismos tende a se estender universalmente. Podemos pensar que o espírito cristão leva a unificar e a superar os preconceitos e as discriminações e a ver os outros solidariamente, inclusivamente, paritariamente, em comunhão e unidade. Por causa da unificadora vontade salvífica de Cristo ou a partir de Cristo e seu Espírito.

\subsection{Não haja divisões entre vós}

O Apóstolo Paulo exorta à unidade e à concórdia. Repreende a comunidade de Corinto pelas rixas e divisões. Deseja a estreita unidade dos fiéis no mesmo espírito e no mesmo modo de pensar. Não haja rivalidades. Não haja divisões. Não se deveria levar a uma visão de "Cristo dividido". E o Apóstolo 
esclarece: "Eu vos exorto, irmãos, em nome de nosso Senhor Jesus Cristo: guardai a concórdia uns com os outros, de modo que não haja divisões entre vós. Sede estreitamente unidos no mesmo espírito e no mesmo modo de pensar. Com efeito, meus irmãos, pessoas da casa de Cloé me informaram de que existem rixas entre vós. Explico-me: cada um de vós diz: 'Eu sou de Paulo!', ou 'Eu sou de Apolo!', ou 'Eu sou de Cristo!' Cristo estaria assim dividido (1Cor 1,10-13)?”

Esse texto, é tradicionalmente, tido como uma chamada para os cristãos divididos. O ecumenismo quer superar discórdias, rixas e divisões, quaisquer que sejam suas causas, tendo em vista a unidade de Cristo. Cristo é o mesmo salvador de todos.

Olhando mais longe, esse procedimento de procurar superar as discórdias e valorizar os laços, uma vez compreendido no seu valor e abraçado na prática, tende a fazer os cristãos desejarem e buscarem também a concórdia universal. Para superar as rixas e discórdias que não têm razão de ser, e ter o pensamento solidário em paz com todos. É um tema a ser cultivado no ecumenismo também mais amplo e universal.

\subsection{A vocação a que fostes chamados}

É a própria vocação cristã que exige de nós andar na unidade, a partir do Espírito. Ao propor a vocação cristã como caminho, e a necessária correspondência com essa vocação, entre outras exigências e virtudes, o autor de Ef faz especial apelo à unidade: "Exorto-vos, pois, eu, o prisioneiro no Senhor, a andardes de modo digno da vocação a que fostes chamados: com toda humildade e mansidão, com longanimidade, suportando-vos uns aos outros com amor, procurando conservar a unidade do Espírito pelo vínculo da paz (Ef 4,1-3)." Desse modo, é mantendo a unidade que se realiza a vocação cristã.

Os versículos seguintes prosseguem o tema, relacionando os fundamentos dessa unidade cristã. O ecumenismo, por sua vez, visa ao cumprimento da vocação.

Um só. O texto imediatamente seguinte, ao que acabamos de ler, apontando para os fundamentos da unidade cristã, afirma a unidade eclesial com a vocação a que foram chamados e ancora essa unidade trinitariamente. Conforme Ef 4,4-6: "Há um só Corpo e um só Espírito, assim como é uma só a esperança da vocação a que fostes chamados; há um só Senhor, uma só fé, um só batismo; há um só Deus e Pai de todos, que está acima de todos, por meio de todos e em todos."

O ecumenismo se firma na unidade eclesial, que se faz com a Trindade. A Trindade é fonte de unidade para a Igreja e o ecumenismo propõe maior 
unidade para que o cristão e todos os cristãos possam viver adequadamente a sua relação com o único Espírito que nos foi dado, com o único Senhor Jesus Cristo, com o único Deus Pai de todos.

Essa orientação para a unidade em relação com Deus faz reconhecer que no fundo todos estão debaixo da unidade divina. A esperança da vocação cristã é una, como um é o Espírito, é um Senhor, é um Deus e Pai.

$\mathrm{O}$ ecumenismo que quer se alimentar dessas afirmações, tende a abrirse, até ver uma unidade de todo o gênero humano em relação com a unidade de Deus único. Isso motiva ainda mais ao diálogo pela unidade do gênero humano, não impondo a convicção religiosa, mas acreditando que a Trindade olha benignamente a todos e a todos quer em unidade.

\subsection{Retomada do tema da unidade no batismo e unidade na eucaristia}

Não foi só em relação às pessoas divinas que se afirmou a unicidade. Afirmou-se a unidade também em relação à fé e ao batismo, introduzidos pelo único Senhor: "Há um só Senhor, uma só fé, um só batismo" (Ef 4,5).

Falamos, já, primeiro, do batismo. Para a devida atenção prática para com esse texto paulino, entre os empreendimentos do ecumenismo se tem buscado as possibilidades de reconhecimento do único batismo. ${ }^{3} \mathrm{O}$ batismo é único, irrepetível, definitivo e suficiente para fazer a pessoa ser verdadeiramente um cristão, um irmão na fé. O batismo, certamente transformador ou recriador, torna a pessoa nova criatura em Cristo. Uma vez batizado, não se batiza de novo. O ecumenismo propõe a possibilidade do reconhecimento do batismo e também que se venha a valorizar mais, em comum, o batismo já recebido, em Semanas de oração, em retiros ecumênicos, ou outras celebrações ou comemorações da fé comum.

Também a fé é uma só. Por isso, é bom que o ecumenismo trabalhe sobre todo o campo da fé, o doutrinal como o prático. Muitas vezes se fomenta o diálogo teológico, para tratar as proposições da fé, a vida da fé, o testemunho da fé, a fé que se recebeu e se abraçou no único batismo. A fé una é motivo de ponderação no ecumenismo e se busca o testemunho comum da fé. Porém, no respeito à consciência, se dialoga sobre a fé, mas não se impõem, pelo ecumenismo, as próprias interpretações e acentuações da fé. Por outro lado, se considera, se valoriza e se explora o aproveitamento da fé compartilhada.

A Eucaristia ocupa lugar central na fé e na vida da Igreja. Ela é sinal e fonte de unidade. Ela é comunhão com Cristo. É o pão único do qual partici-

\footnotetext{
${ }^{3}$ Cf. CONSELHO PONTIFÍCIO PARA A PROMOÇÃO DA UNIDADE DOS CRISTÃOS, Diretório para a aplicação dos princípios e normas sobre o ecumenismo, São Paulo, Paulinas, 1994, n. 94.
} 
pamos. São várias as referências paulinas ao tema da Ceia ou da comunhão do pão eucarístico. Destacamos a que mais importa à nossa ilustração da unidade.

O Apóstolo Paulo nos brinda com belíssimo texto sobre a unidade no pão eucarístico: "O cálice de bênção, que abençoamos, não é comunhão com o sangue de Cristo? O pão, que partimos, não é comunhão com o corpo de Cristo? Já que há um único pão, nós, embora muitos, somos um só corpo, visto que todos participamos desse único pão (1Cor 10,16-17)." O Apóstolo Paulo vê no pão de bênção compartilhado um fundamento da unidade do corpo de Cristo, ao qual pertencemos.

Quem trabalha pelo ecumenismo não deixará de valorizar a Ceia eucarística como sinal de unidade. $\mathrm{O}$ ecumenismo caminhará na esperança da plena comunidade eucarística. O Conselho Mundial de Igrejas tem a celebração comum da Eucaristia como o objetivo final do ecumenismo. ${ }^{4}$

Por outro lado, a unidade cristã no batismo e a meta da unidade cristã na Eucaristia não diminuem ou constrangem o diálogo universal. Antes, empenham mais o cristão no senso da unidade, bem como servem de ponto de partida e alimento para uma vida comprometida com a busca de unidade. No respeito das diferenças, existe entretanto uma aspiração de unidade e comunhão que é muito humana, e que assim ultrapassa a fronteira da profissão de fé cristã. Aliás, Paulo não introduziu nem inventou o rito do batismo nem a imagem da bênção eucarística. Recebeu esses conceitos e imagens do judaísmo e do helenismo e tratou deles de modo cristão. O diálogo universal deverá encontrar no testemunho e no comprometimento dos cristãos, uma nova contribuição no caminho da unidade de todos.

\subsection{Unidade com diversidade, pelo mesmo Espirito}

Também as referências ao corpo de Cristo aparecem no Apóstolo Paulo em abordagens diversas. Importa-nos aqui, principalmente, a imagem eclesiológica do corpo com os muitos membros, por ser um especial fundamento ecumênico. É uma imagem muito estudada, segundo se pensa em metáfora ou realidade, e nas relações que tenha com Cristo. Está certamente relacionada com a cultura helenística. Sem pretender ser uma alegoria, acentua a relação e a unidade entre os membros do corpo, e faz uma referência ao próprio Cristo, como centro da comparação. A teologia da Igreja como corpo de Cristo tem

\footnotetext{
${ }^{4}$ A comissão Fé e Constituição do Conselho Mundial de Igrejas proclama como sua meta ecumênica: "proclamar a unidade da Igreja de Jesus Cristo e chamar as Igrejas para a meta da unidade visível em uma fé e uma comunidade eucarística expressa no culto e na vida comum em Cristo, para que o mundo creia": <www.wcc-coe.org>, acesso em 28/nov/1999.
} 
diferentes desenvolvimentos, não aparecendo de modo igual nas grandes cartas ou nas do cativeiro.

A 1Cor, o Apóstolo Paulo iniciou com uma exortação à unidade e irá incluir um poema como hino à caridade, contemplando a caridade como principal dos carismas. Nessa carta, ele usa a imagem do corpo e nos faz pensar na relação da unidade com a diversidade.

O Apóstolo discorre sobre a unidade do corpo com a diversidade dos membros, logo após ter considerado a diversidade de carismas para a utilidade de todos: "Há diversidade de dons, mas o Espírito é o mesmo; diversidade de ministérios, mas o Senhor é o mesmo; diversidade de modos de ação, mas é o mesmo Deus que realiza tudo em todos. Cada um recebe o dom de manifestar o Espírito para a utilidade de todos. [...] É o único e mesmo Espírito que isso tudo realiza, distribuindo a cada um os seus dons, conforme lhe apraz (cf. 1Cor 12,4-11)."

No versículo imediatamente seguinte, ele afirma a unidade do corpo com muitos membros diferentes e aplica essa imagem ao próprio Cristo: assim "acontece com Cristo". A unidade é também alicerçada na diversidade: "Com efeito, o corpo é um e, não obstante, tem muitos membros, mas todos os membros do corpo, apesar de serem muitos, formam um só corpo. Assim também acontece com Cristo (1Cor 12,12)."

Desse modo, o corpo de Cristo é corpo de muitos membros, cada qual com a sua função, cada qual com os seus carismas. E os cristãos são esses membros de Cristo. É a sua conclusão. Diz, em 1Cor 12,27: "Ora, vós sois o corpo de Cristo e sois os seus membros, cada um por sua parte".

Como membros diferentes do corpo, cada qual tem que se honrar da própria contribuição e valorizar a contribuição do outro, pois todos têm uma função no corpo. Além disso, todos haveriam de se alegrar ou sofrer com cada membro, solidariamente.

Esse é um tema fundamental da eclesiologia paulina. Devemos considerá-lo igualmente fundamental para a perspectiva ecumênica. Não é novidade, mas também não é supérfluo lembrar que é importante no campo do ecumenismo, falar de unidade e diversidade, de identidade e de alteridade, de diferenças que se respeitam e que se somam.

Cabe pensar, porém, o quanto ainda podemos crescer ecumenicamente, pela contemplação da imagem paulina, até de fato valorizarmos o que o Espírito concedeu a cada qual, a cada tradição, a cada espiritualidade cristã, para enriquecer o patrimônio cristão transmitido na Igreja, o testemunho cristão no mundo, a vida cristã no conjunto dos fiéis e compartilhamento de dons que os fiéis são chamados a fazer entre si, no diálogo, no convívio, na mútua ajuda, para a edificação de todos. 
$\mathrm{O}$ que se falou de unidade e diversidade parece não ter sido ainda suficiente. Estamos ainda a caminho de buscar uma aproximação e de desenvolver o diálogo ecumênico sem rivalidades e no mútuo serviço. $\mathrm{O}$ ecumenismo ainda está aprendendo com as palavras do Apóstolo Paulo.

Se antes nos referimos à teologia da unidade no batismo e da unidade na Eucaristia, aqui acentuamos a relação tanto do batismo como da Eucaristia com o único Espírito. Assim também Paulo faz ver no Espírito, um só Espírito, a fonte de unidade. Diz 1Cor 12, 13: "Pois fomos batizados num só Espírito para ser um só corpo, judeus e gregos, escravos e livres, e bebemos de um só Espírito."

Não será difícil perceber que a unidade e a diversidade, que valorizamos no ecumenismo estrito dos cristãos, podem ser também inspiradoras para a solidariedade e para o aproveitamento de riquezas, percepções e contribuições de pensamento e ação em função de um diálogo universal, inter-religioso e sem fronteiras. Certamente o Espírito, que sopra onde quer, deixa também seus dons e seus impulsos para além das fronteiras visíveis dos cristãos. Seria esse um modo cristão de apreciar que o diálogo e a unidade de todos se beneficiará dos dons e das riquezas religiosas e humanas que possam ser compartilhadas com outros ou percebidas e recebidas de outros.

\subsection{O Corpo e a Cabeça; Unidade e crescimento}

$\mathrm{O}$ ecumenismo promove a unidade na diversidade. Trata-se de reconhecer o que é próprio de cada qual, para a utilidade de todos. O que é dom do Espírito distribuído entre cristãos e tradições. Todos esses dons, que se tornam tantas contribuições, podem confluir no enriquecimento de todos. O que é dom de cada qual deve ser cultivado, guardado, aproveitado. E com todos a Igreja se edifica.

A concepção eclesiológica do corpo tem em Ef novo desenvolvimento, que sob algum aspecto retoma as dimensões presentes nas grandes cartas, $\mathrm{e} \mathrm{Cl}$, e vai além. É colocada com novas perspectivas - entre as quais destacamos aqui os aspectos de unidade e crescimento. Além da já suposta unidade do corpo, acentua-se a unidade com Cristo como a Cabeça, que dá o controle e da qual deriva a vida e o crescimento. Fala-se da coesão e da edificação do Corpo e do seu crescimento na direção de Cristo. Outros conceitos são importantes, como o da nova humanidade em Cristo, ou o de plenitude, ligado não só a Cristo, mas também ao tema da Igreja em $\mathrm{Cl}$ e em Ef , que nos permitiria ver o âmbito cósmico repleto de Cristo e o lugar da Igreja nesse contexto. Quanto à metáfora do Corpo e da Cabeça, aspecto que destacamos, dá lugar às relações da coesão do corpo e sua subordinação à Cabeça. É interessante que a unidade 
se coloca como um alvo de maior perfeição e se mostra o crescimento eclesial realizado mediante a verdade e o amor de Cristo.

Diz Ef 4, 12-16: "para aperfeiçoar os santos em vista do ministério, para a edificação do Corpo de Cristo, até que alcancemos todos nós a unidade da fé e do pleno conhecimento do Filho de Deus, o estado do Homem Perfeito, a medida da estatura da plenitude de Cristo [...] seguindo a verdade em amor, cresceremos em tudo em direção àquele que é a Cabeça, Cristo, cujo Corpo, em sua inteireza, bem ajustado e unido [...] realiza seu crescimento [...]".

Todos esses tópicos são iluminadores para o ecumenismo, pois a unidade é escatológica e a Igreja cresce já com o dom da unidade para uma maior unidade, até a sua perfeição, a sua maturidade total. Ou seja, a Igreja como Corpo de Cristo está em crescimento para a sua plena estatura. A unidade eclesial também cresce para a maturidade.

O ecumenismo leva isso em conta e tem esperança nisso. Por sua vez, como tarefa de movimentar-se na direção de Cristo como Cabeça, o ecumenismo quer favorecer a unidade da Igreja em crescimento e o crescimento da Igreja com maior unidade.

Por outro lado, para a Igreja, em diálogo com outras religiões, pode-se ter em vista que a plenitude de Cristo se estende cosmicamente, de modo que a Igreja poderia sentir-se ligada em Cristo com todas as pessoas e todo o universo. O diálogo e a colaboração favorecem o seu próprio crescimento (não estamos nos referindo a números, mas à maturidade, o estado mais perfeito, o maior conhecimento do próprio Cristo). Todos podem crescer na coesão. $\mathrm{O}$ ministério se faz na profissão e na prática da "verdade em amor". Nisso, os laços dos cristãos com as outras pessoas e a atuação de todos no mundo podem sempre se aperfeiçoar.

\subsection{Unidade da reconciliação e da paz}

A Igreja crê que Cristo é centro de unidade e de crescimento. Outro aprofundamento se faz nos conceitos de paz e de reconciliação. O tema da reconciliação aparece em diversos textos paulinos, com matizes próprios. Assim o encontramos principalmente em 2Cor 5,18-21; em Rm 5,8-11; em Cl 1,20-22; em Ef 2,14-17.

Em 2Cor 5,18-21 temos a afirmação de alguém ser "em Cristo" uma "nova criatura", porque "se fez uma realidade nova", o que "vem de Deus, que nos reconciliou consigo por Cristo e nos confiou o ministério da reconciliação". Era "Deus que reconciliava o mundo consigo" e o Apóstolo suplica: "reconciliai-vos com Deus". 
Em Rm 5,8-11 se mostra que "fomos reconciliados com Deus pela morte de seu Filho, muito mais agora, reconciliados, seremos salvos por sua vida, "e nos gloriamos em Deus por nosso Senhor Jesus Cristo, por quem desde agora recebemos a reconciliação".

Outro matiz encontramos em $\mathrm{Cl}$ 1,20-22, quando a teologia, referida a Cristo, faz ver nEle, Cristo, Cabeça da Igreja, que é o seu Corpo aquele em quem "aprouve a Deus fazer habitar toda a Plenitude e reconciliar por ele e para ele todos os seres, os da terra e os dos céus, realizando a paz pelo sangue de sua cruz".

Destacamos aqui o último dos textos que indicamos, e que tem sido explorado de modo particular na teologia do ecumenismo. É o texto de Ef 2, 14.16.

Cristo é denominado como nossa Paz. Nele ambos os povos - de judeus e de gentios - se tornam um só. Nele se superam as inimizades, os particularismos étnicos, os conflitos pelas identidades e prerrogativas de cada um, a superação da inimizade, em função de uma reconciliação. O fundamento disso é a obra da reconciliação que é reconciliação com Deus, proporcionada por Cristo. A reconciliação com Deus constitui um fundamento de unidade, colocando todos na unidade de um Corpo. Essa reconciliação se fez na redenção da Cruz. Diz Ef 2,14. 16: "Ele é a nossa paz: de ambos os povos fez um só, tendo derrubado o muro de separação e suprimido em sua carne a inimizade, [...] a fim de criar um só Homem Novo, e de reconciliar a ambos com Deus em um só Corpo, por meio da Cruz".

Por meio de Cristo somos reconciliados com Deus e se suprime a inimizade, Existe uma dupla implicação da obra da reconciliação. O tema da reconciliação envolve a reconciliação com Deus, ou seja, reconciliação nossa ou de todos os seres humanos e de todos os povos com Deus, e a reconciliação envolve a unidade das pessoas e dos povos. Um aspecto não se separa do outro, antes estão mutuamente implicados. Com tudo isso, o tema da reconciliação tem se tornado caro ao ecumenismo. O ecumenismo deriva do espírito de reconciliação com Deus. Autores "ecumenistas" pensam na unidade dos cristãos como unidade reconciliada, ou na reconciliação como caminho de unidade. A reconciliação é fundamento de nova relação entre as pessoas, os povos.

O ecumenismo pode e deve se inspirar no tema paulino da reconciliação e na contemplação da Cruz para promover o interesse pela reconciliação e trabalhar nesse sentido. A fé cristã é fé em Cristo que redime, e a Cruz é símbolo dessa redenção e reconciliação. A obra cristã deve ser decorrente da fé e concretização dessa reconciliação.

A reconciliação é palavra atual para a teologia do ecumenismo. Vale para a unidade dos cristãos, vale para o diálogo inter-religioso, vale para todas as pessoas. É grande desejo de nossos tempos. Representando esse desejo, a 
ONU fala em reconciliação como tema para consideração especial do ano de 2009. De fato, entre outros títulos, este é um "ano internacional da reconciliação".

Para os cristãos, a Paz, que é Cristo, é dom de reconciliação, também com o perdão, um estado de novo ser, nova vida e nova relação. É portanto, mais que uma quietude. É também superação da inimizade. Essa paz em Cristo torna-se luz para a busca da paz universal.

Se a reconciliação é desejo de muitos, o que não se dirá da paz? Com efeito, a paz não é somente desejo dos cristãos. A paz é, com efeito, desejo profundo de todos os corações. A paz é aspiração para todas as religiões. É natural que as pessoas queiram encontrar a paz interior, encontrar a paz na vida das comunidades, encontrar a paz entre as nações. Um interesse comum, que o diálogo inter-religioso pode promover, portanto, é o serviço da paz, a mediação para a paz, o cultivo dos elementos que criam e fortalecem a paz.

Os cristãos levam a sua contribuição a partir de Cristo. Os frutos e os serviços da redenção são de paz para todos. Não se podem restringir ao horizonte de um só povo, o povo cristão, ou apenas às igrejas cristãs reconciliadas em unidade. Por causa de Cristo, os cristãos empreendem a paz universal. Os cristãos devem contribuir para a paz levados pelo próprio Cristo e em função de sua fé e vida em Cristo. Podem e devem acolher o desejo e a contribuição dos outros para a paz. Colaborar para a paz.

\subsection{Caridade}

O Apóstolo Paulo proclama a justificação pela fé em Cristo. Esta fé envolve numa vida a partir de Cristo. Podemos dizer que esta fé em Cristo opera na caridade, manifesta-se com a caridade. São inúmeras as exortações do Apóstolo em vista de uma prática de caridade. Trata-se da "fé agindo pela caridade" (Gl 5,6). Trata-se do cumprimento de toda a Lei porque "a caridade é a plenitude da Lei" (Rm 13,10).

$\mathrm{Na} 1 \mathrm{Cor}$, que tanto falou da unidade, e enalteceu a diversidade de carismas, o Apóstolo conclama todos à caridade como dom mais importante: "permanecem fé, esperança, caridade [...] a maior delas, porém, é a caridade".

A importância da caridade ou do amor se vê ainda quando "o amor de Cristo nos impele" (2Cor 5,14). E quando o Apóstolo deseja "que o vosso amor cresça cada vez mais". Em outra carta, diz: "Revesti-vos da caridade, que é o vínculo da perfeição" $(\mathrm{Cl} 3,14)$. E o plano de Deus é "para sermos santos e irrepreensíveis diante dele no amor". 
O pedido de Paulo a Filêmon era "para que tua ação não fosse forçada, mas espontânea" (Fm 14). E para Timóteo, "a finalidade desta admoestação é a caridade".

Seria impossível que o ecumenismo ficasse surdo a tanta insistência na caridade. O objetivo do ecumenismo é promover a unidade na caridade. Afirma o Decreto UR: "em tudo cultivem a caridade". ${ }^{5} \mathrm{O}$ ecumenismo também se aplica em campanhas e obras comuns de serviço da caridade, para que se mostre em obras de caridade a diaconia de Cristo. ${ }^{6}$

As religiões costumam pregar a "regra de ouro": fazer o bem que se desejaria para si (Mt 7,12; Lc 6,31). Podem em diálogo se aproximar para a caridade.

\section{A oração no ecumenismo}

No Ecumenismo tem lugar fundamental a oração. Ora-se pela unidade, ora-se em unidade. A Semana de Oração pela Unidade dos Cristãos é celebrada em duas ocasiões do ano: de 18 a 25 de janeiro, concluindo-se com a festa da "conversão de Paulo". Da Ascensão a Pentecostes, concluindo-se com a celebração da efusão do Espírito Santo.

A Semana de Oração pela Unidade teve em 2008 a celebração do seu centenário com um texto paulino: 1Ts 5,12a. 13b-18. O lema foi: "Orai sem cessar" (v. 17).

O texto é muito interessante para a prática geral do ecumenismo. Extraímos algumas afirmações:

"Nós vos rogamos, irmãos: Vivei em paz entre vós [...] admoestai os indisciplinados, reconfortai os pusilâmines, sustentai os fracos. Sede pacientes para com todos [...] que ninguém retribua o mal com o mal; procurai sempre o bem uns dos outros e de todos. Alegrai-vos [...] Orai sem cessar. Por tudo dai graças."

Desde 1968 são propostos anualmente temas e textos bíblicos para a celebração da semana e praticamente a metade desses textos foi tirada das cartas paulinas. A começar pelas três primeiras semanas, preparadas em conjunto, nos três primeiros anos (1968, 1969 e 1970), em que os respectivos temas foram: "Para o louvor de sua glória" (Ef 1,14); "chamados à liberdade" ( a partir de Gl 5,13); "Somos os colaboradores de Deus" (inspirado em 1Cor 3,9). Entre

\footnotetext{
${ }^{5}$ Cf. $U R$, n. 4.

${ }^{6}$ Cf. $U R$, n. 12 . UUS, n. 40.
} 
os aproximadamente vinte temas paulinos meditados, poderíamos ver o ecumenismo contar com a esperança em Cristo - "A esperança não decepciona" ( $\mathrm{Rm}$ 5,5), o tema da unidade com a diversidade - "Um só Espírito, diversos dons" (1Cor 12), ou no Ano do Grande Jubileu de 2000: "Bendito seja Deus que nos abençoou em Cristo" (Ef 1,3); muito especial o tema da nossa fragilidade levando o tesouro de Cristo: "Este tesouro, nós o carregamos em vasos de argila" (2Cor 4,7). No centenário da Semana de Oração, como vimos, se insiste na oração "sem cessar".

\section{5, O diálogo da justificação - entre cristãos}

\subsection{Um tema paulino muito controvertido entre os cristãos}

Quanto São Paulo defendeu a unidade eclesial, é paradoxal que a teologia paulina tenha sido tema de profundas controvérsias entre os cristãos. Entretanto, o tema paulino da justificação foi central nas controvérsias da Reforma. Os termos "justiça", "justo", "justificar" aparecem na teologia paulina mais de 100 vezes, aplicados em contextos e sentidos variados, e não se teve um consenso de sua interpretação. Antes, a história da interpretação da justiça de Deus e da justificação apresenta linhas muito diversas, muitas vezes complementares, mas não raro levadas ao confronto e ao conflito.

Com efeito, entre tantas afirmações sobre a justiça de Deus e a justificação, o Apóstolo afirma que somos justificados pela fé (cf. Gl 3,11; $\mathrm{Rm} 1,16,17)$, mas avultaram as discussões sobre o significado da justificação e sobre a relação da fé ou da justificação com a salvação ou com a renovação interior, também com a questão do homem ser santo ou pecador ou inclinado ao pecado, e com a exigência ou a responsabilidade das obras. Nem sempre se leva devidamente em conta o horizonte vétero-testamentário que certamente estava no contexto do Apóstolo Paulo - e que pode fazer ver a justiça de Deus em relação com sua fidelidade à aliança e sua ação salvífica -, como nem sempre as interpretações vêem bem qual teria sido o propósito da afirmação paulina de que o homem não se justifica pelas obras da Lei. Seria interessante considerar a distinção entre ser levado na fé ao que ela exige ou ter alcançado a salvação a partir das próprias obras, e a distinção entre aceitar a Lei, o propósito e a realização da Lei, como expressão da Aliança, ou a exigência de uma que caracteriza o judaísmo de modo a excluir o não judeu do alcance da bênção da aliança dada como graça, universalmente, em Cristo.

São muitas as abordagens e as propostas de solução. As interpretações, vistas em confronto, algumas vezes se tornaram extremadas ou se mostraram excludentes entre si. Seguiram paralelamente sugestões diversas nas tradições 
católica, luterana, calvinista, metodista... Recentemente a discussão tem se aprofundado muito e seguem ainda hoje os estudos exegéticos e teológicos, sem que possamos ter em vista uma solução consensual, mas já contando com grande avanço no conhecimento da teologia paulina e conhecendo também a complexidade ou a conciliação de muitos aspectos que antes não costumavam ser aproximados.

\subsection{O tema paulino da justificação levado ao diálogo ecumênico}

O ecumenismo empreende também o diálogo teológico e o tema da justificação foi objeto de cuidadoso diálogo ecumênico e ao ponto de trazer à luz um documento importante no caminho da unidade. Era praticamente inesperado que o diálogo ecumênico tratasse a justificação e o tema da justificação mostrasse uma aproximação significativa e agora estivesse no caminho da reintegração da unidade.

A Declaração Comum sobre a Doutrina da Justificação, entre luteranos e católicos, de 1999, foi mais que um passo simbólico de diálogo, pois mostrou possibilidades de verdadeiro progresso na discussão teológica entre perspectivas diferentes. Mais tarde o documento recebeu o acordo também de metodistas.

O diálogo viu diferentes concepções e acentuações teológicas, juntamente com idéias fundamentais que se puderam compartilhar e pôde chegar a uma declaração comum que já constitui um marco na história do ecumenismo. A contraposição entre fé e obras mostra não poder se sustentar para nenhuma parte dos dialogantes. Aceita-se tanto a justificação pela graça, na fé, e não por mérito nosso, como também o lugar das obras, pois somos capacitados e chamados às boas obras pelo Espírito. É um dos pontos fundamentais da declaração comum:

"Confessamos juntos: somente por graça, na fé na obra salvífica de Cristo, e não por causa de nosso mérito, somos aceitos por Deus e recebemos o Espírito Santo, que nos renova os corações e nos capacita e chama para boas obras".

E ainda, é pela graça que Deus justifica e perdoa, e presenteia com vida nova:

\footnotetext{
${ }^{7}$ Cf. Declaração Conjunta sobre a Doutrina da Justificação, Declaração conjunta CatólicaRomana e Federação Luterana Mundial. Augsburgo, 31 de outubro de 1999, São LeopoldoBrasília-São Paulo: Sinodal-CONIC-Paulinas, $2000\left(3^{\mathrm{a}}\right)$, n. 15.
} 
"Deus, por graça, perdoa ao ser humano o pecado e o liberta [...]. Justificação e perdão dos pecados é ser feito justo, com o que Deus 'presenteia nova vida em Cristo"". 8

As diferenças de perspectivas e visões teológicas são respeitadas e registradas:

"Luteranos e Católicos, conjuntamente, podem compreender o cristão como 'simul iustus et peccator', a despeito de suas abordagens diferentes dessa temática, como exposta na DC 29-30".

Como exemplo de diferenças de linguagem, indica-se:

“O conceito da 'concupiscência' é usado em sentido diferente por católicos e luteranos". 9

Explicitam-se tópicos de acentuação ou formulação própria de cada tradição:

"A realidade da salvação recebida no batismo e a ameaça através do poder do pecado podem ser expressas de tal maneira que, por um lado o perdão dos pecados e a renovação da pessoa em Cristo pelo batismo é enfatizada, e, por outro lado, pode ser visto que a pessoa justificada está continuamente exposta ao poder do pecado e suas investidas, não estando isenta da luta vitalícia contra a oposição a Deus."10

Alguns pensam que a declaração comum é um acordo insuficiente e mesmo artificial, tentando conciliar inutilmente as divergências. Parece, ao contrário, que se trata de um avanço significativo de conciliação de perspectivas, sem pretender ser o final da conversação. O documento chega a um grau de consenso e supera razões de condenação:

"Com base nas concordâncias alcançadas na DC sobre a Doutrina da Justificação, a Federação Luterana Mundial e a Igreja Católica declaram junas:

A compreensão da doutrina da justificação exposta nesta Declaração mostra que entre luteranos e católicos há um consenso em verdades básicas da doutrina da justificação"

\footnotetext{
${ }^{8}$ Cf. $D C$, n. 22.

${ }^{9} \mathrm{Cf}$. $D C$, Anexo, $2 \mathrm{~A}$ e B.

${ }^{10} \mathrm{Cf}$. $D C$, Anexo 2 B.
} 
(DC, n. 40). E, por isso, “a doutrina expressa nessa DC não é alvo das condenações de parte a parte."

Como verdadeiro fruto de diálogo e respeito pelas perspectivas, formulações e acentuações de cada qual, a DC reúne vários procedimentos. Entre eles:

$\left.1^{o}\right)$ Faz afirmações comuns fundamentais, do tipo "confessamos juntos".

$2^{o}$ ) Desenvolve alguns aspectos importantes da doutrina, conciliando as perspectivas.

$3^{o}$ ) Acrescenta, de modo distinto e pacífico, elementos que são abordados e formulados diversamente nas diferenças de linguagem ou de interpretações e ênfases, reconhecendo aspectos diversos nas respectivas teologias, de luteranos e de católicos. Isso, porém, não anula o compartilhamento de verdades fundamentais, ao ponto de superar as mútuas condenações e as desconfianças iniciais.

$4^{o}$ ) O documento está aberto ao prosseguimento do diálogo e ao aprofundamento do estudo.

O prosseguimento do estudo e do diálogo deve certamente levar em conta as várias linhas de reflexão que se interpuseram na história da interpretação de Paulo, propondo uma reflexão enriquecida, mas também equilibrada, onde se corrigem posições extremadas ou de pouco fundamento na doutrina paulina ou de sua complementação com outros textos do Novo Testamento. O estudo e o diálogo sobre o tema têm se beneficiado recentemente dos frutos da exegese paulina, particularmente quando ela é vista junto com o pano de fundo vétero-testamentário da fidelidade de Deus e sua ação salvífica. Nessa orientação, a justiça de Deus é então "o amor clemente e a intervenção redentora de Deus no mundo por intermédio de Cristo". E assim "a encarnação da justiça de Deus na obra redentora da cruz leva ao perdão, e o perdão restaura relações". ${ }^{12}$ A injustiça dos homens se mostra na sua desobediência, em recusar reconhecer Deus ou faltando contra o relacionamento da aliança, mas o Evangelho é poder de Deus para a salvação, pela libertação realizada em Jesus Cristo. É um tema paulino particularmente abordado em Rm 1-3. A aceitação desse dom de Deus se faz na fé, que conduz a uma vida conforme Deus. A fé opera pela caridade $(\mathrm{Gl} 6,5)$. Pode-se pensar que ser "justiça de Deus" (2Cor 5,21) é receber a justiça de Deus e ficar restaurado na relação com Deus, e em Deus tornar-se extensão do seu amor.

\footnotetext{
${ }^{11}$ Cf. DC, n. 41.

${ }^{12}$ Cf. K. L. ONESTI - M. T. BRAUCH, "Justiça, justiça de Deus" in G. E. HAWTHORNE R. P. MARTIN (org.), Dicionário de Paulo e suas cartas. São Paulo - Paulus - São Paulo: Vida Nova - São Paulo: Loyola, 2008.
} 


\section{O Ano Paulino - e a aproximação entre católicos e ortodoxos}

O Ano Paulino tem, por muitos motivos, implicação ecumênica. Entre esses motivos, figuram:

$1^{\circ}$ ) a ressonância ecumênica da teologia paulina, que trata tão profundamente da unidade em Cristo;

$2^{o}$ ) lembrar o fato de que o diálogo com os evangélicos se dedicou de um modo especial a um tema paulino, que se tornou controvertido, mas que agora é motivo de esperança para o ecumenismo;

$3^{o}$ ) ver também como católicos e ortodoxos, cada um por sua parte, mas de modo próximo, celebram o Ano Paulino. Este é mais um ponto de experiência ecumênica concreta a caminho da unidade com Paulo.

O Patriarcado Ecumênico anunciou o aniversário do Apóstolo Paulo em carta encíclica para todas as suas Igrejas no Natal de 2007. A abertura do Ano Paulino na Igreja Católica em junho de 2008 se fez com discurso do Papa Bento XVI e recebeu as palavras fraternas de Bartolomeu I, Patriarca Ecumênico de Constantinopla. ${ }^{13}$

O Papa Bento XVI, na abertura do Ano Paulino, acolheu a presença amiga do patriarca:

"Foi com prazer que tomei conhecimento que também Vossa Santidade proclamou um Ano Paulino. Esta feliz coincidência salienta as raízes da nossa comum vocação cristã e a significativa sintonia - que estamos a viver - de sentimentos e de compromissos pastorais".

Nessa saudação, o Papa viu em Paulo um chamamento de unidade e manifestou esperança e desejo de que a unidade possa exprimir-se plenamente:

"São Paulo recorda-nos que a plena comunhão entre todos os cristãos encontra o seu fundamento 'num só Senhor, numa só fé e num só batismo' (Ef 4, 5. Por isso, que a fé comum, o único Batismo... e a obediência ao único Senhor e Salvador, possam o quanto antes, exprimir-se plenamente na dimensão comunitária e eclesial".

\footnotetext{
${ }^{13}$ Os discursos de Sua Santidade, o Papa Bento XVI, e de Sua Santidade, o Patriarca Bartolomeu I, são citados sobre a tradução portuguesa editada pelo jornal vaticano L'Osservatore Romano (OR). Para o primeiro discurso, ver "O Apóstolo Paulo indica o caminho para a unidade dos cristãos" - Encontro de Bento XVI com Bartolomeu I para a inauguração do Ano Paulino, em $O R, 5$ de julho de 2008 , p. 2 . O outro discurso vem apresentado sob o título "União da fé e comunhão do espírito".
} 
Utilizando a teologia paulina, o Papa apontou para os fundamentos da unidade:

"Um só Corpo e um só Espírito, afirma o Apóstolo das Nações, e acrescenta; "Fostes chamados a uma única esperança” $($ Ef 4, 4).

Além disso, vê em São Paulo um critério:

"São Paulo indica-nos um caminho seguro para conservar a unidade e, no caso da divisão, para o seu restabelecimento".

O Papa menciona a exortação de Paulo aos Coríntios e olha o nosso tempo e vê a importância do testemunho de unidade dos cristãos:

"No nosso mundo em que se vai consolidando o fenômeno da globalização, mas, entretanto, continuam a persistir divisões e conflitos, o homem sente uma crescente necessidade de certeza e de paz".

Por sua vez, o Patriarca Bartolomeu I, expressou alegria de participar das cerimônias católicas pela solenidade dos Apóstolos São Pedro e São Paulo e valorizou a bênção que deixaram para a Igreja Universal:

"É com sentimentos de sincera alegria e de agradecimento autêntico que participamos dos serviços solenes na ocasião da festa abençoada dos Santos Padres Pedro e Paulo, Padroeiros Apostólicos da Igreja primitiva da Roma Antiga. Através dos tempos, o derramamento do seu sangue sagrado mostrou-se uma bênção para a Igreja Cristã Universal.

O Patriarca Ecumênico viu na ocasião o momento de um compromisso ecumênico:

"Esta jubilosa celebração também é uma ocasião para as nossas duas Igrejas irmãs orarem e celebrarem juntas de modo a selar o nosso compromisso de reconciliação e fortalecer os nossos laços de solidariedade."

O Patriarca fala da celebração comum do aniversário do Apóstolo Paulo:

“Outra razão de sincera alegria é a minha presença aqui, 
junto com os peregrinos do Patriarcado Ecumênico de todo o mundo, para participar na abertura oficial do Ano Paulino, que uma vez mais as nossas respectivas Igrejas celebram durante o aniversário do nascimento do Apóstolo dos gentios, São Paulo [...]"

O Patriarca fala do testemunho vivo de Cristo Crucificado e Ressuscitado, como proclamava o Apóstolo Paulo:

"Lá, nas Igrejas da Ásia Menor, a pequena centelha do princípio do Cristianismo é visível e vibrante até ao dia de hoje como um testemunho vivo de uma verdade eterna sobre o Senhor Crucificado e Ressuscitado, como foi proclamado pelo grande Apóstolo Paulo.”

O Patriarca também invoca a bênção de São Pedro e São Paulo, desejando que eles inspirem a visão eclesial e a missão apostólica.

\begin{abstract}
"Santidade, gostaríamos de expressar a nossa fervorosa gratidão pelo convite que nos foi feito para partilhar estas solenes festividades. Que os grandes Fundadores e Padroeiros Apostólicos São Pedro e São Paulo, intercedam por todos nós... Possam eles continuar a inspirar-nos com a amplitude das suas visões eclesiais e com a determinação da sua missão apostólica".
\end{abstract}

\title{
Conclusão
}

Percorremos um caminho de contemplação de Paulo. Primeiro, como exemplo e síntese de diálogo, inspirador para o diálogo também no ecumenismo. Em seguida, considerando vários aspectos de sua teologia e refletindo sobre a incidência desses temas para o interesse ecumênico. Observamos como o diálogo ecumênico progrediu na superação da maior controvérsia da teologia paulina. Consideramos, enfim, as palavras de amizade e de ecumenismo trocadas pelo Papa Bento XVI e o Patriarca Ecumênico Bartolomeu I por ocasião da abertura do Ano Paulino. Tudo isso faz-nos ver como é oportuno ter Paulo em vista, quando se trata de empreender ou de renovar o ecumenismo.

Podemos afirmar que o Apóstolo Paulo ilumina o ecumenismo. O ecumenismo pode se esclarecer e se alimentar, buscar critérios e sugestões na teologia de Paulo. Ela pode nos inspirar e confortar na busca de maior unidade. Isso vale, desde logo, para a maior unidade dos cristãos, mas não faltam 
instigação e luz para levar os cristãos ao interesse e ao empenhamento pelo diálogo mais amplo mesmo em âmbito universal.

\section{Maria Teresa de Freitas Cardoso}

Doutora pela PUC-Rio

Professora do Departamento de Teologia da PUC-Rio 